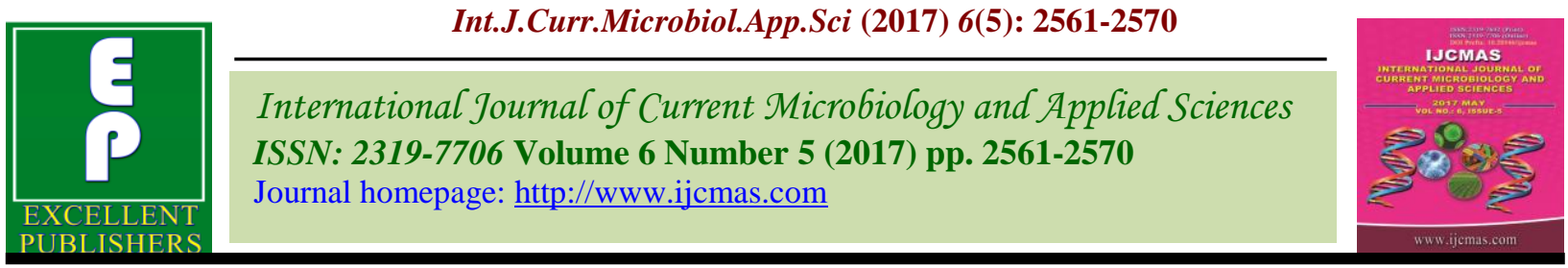

Original Research Article https://doi.org/10.20546/ijcmas.2017.605.288

\title{
Chemo-Morphic Traits Determining Seed Yield in Sesame as Influenced by Growing Seasons
}

\author{
S.P. Monalisa* and S.K. Swain \\ Department of Seed Science and Technology, OUAT, Bhubaneswar, India \\ *Corresponding author
}

\section{A B S T R A C T}

\begin{tabular}{|c|}
\hline Keywords \\
\hline $\begin{array}{l}\text { Chemo- } \\
\text { morphic, } \\
\text { Season, } \\
\text { Sesame, Traits }\end{array}$ \\
\hline Article Info \\
\hline $\begin{array}{l}\text { Accepted: } \\
\text { 25 April } 2017 \\
\text { Available Online: } \\
10 \text { May } 2017\end{array}$ \\
\hline
\end{tabular}

An investigation was undertaken during summer 2015, kharif 2015 and rabi 2015-2016 at the Central Research Institute and department of Seed Science and Technology, OUAT, Bhubaneswar to find out the influence of growing seasons on various chemo-morphic traits determining plant growth and seed yield in five varieties/genotypes of sesame viz., Uma, Amrit, Nirmala, Prachi, Cums 17. Observations were recorded on six plant growth characteristics viz., days to initiation and completion of 50\% flowering, days to initiation of capsules, plant height and number of primary and secondary branches, six yield attributes namely number of capsules/plant, seeds per capsule, length, width and thickness of capsules, 1000 seed weight and per plant seed yield. The pooled values of different traits over 3 growing seasons indicated that Prachi was the earliest to initiate flowering (33.57 days) and complete 50\% flowering (40.57 days), 1000 seed weight( $3.12 \mathrm{~g}$ ) and per plant seed yield $(8.207 \mathrm{~g})$. However, the higher seed yield $(8.045 \mathrm{~g})$ in Nirmala was due to increased number of capsules per plant (61.01) and number of seeds per capsule (48.69). The pattern of variation of different traits among the varieties was found to be similar in all the three growing seasons. The results indicated that the kharif season is ideal time for Sesamum seed production followed by summer season.

\section{Introduction}

Sesame (Sesamum indicum L) is considered one of the most important and oldest oil seed crops that belong to the pedaliaceae family (Noorka et al., 2011). Africa is considered to be the primary center of origin of this crop because of the presence of its diverse wild species in that content. India is the second center of origin and another secondary center is japan. The sesame seeds are important source of oil which contains about $21.5 \%$ protein, $60.8 \%$ fat, $8.9 \%$ carbohydrate and $3.4 \%$ ash (Nanda and Agrawal, 2009). Sesame is a rainfed crop and requires 45-50 $\mathrm{cm}$ rainfall. It thrives well in areas having 21-
230 temperature, frost, prolonged drought and heavy rains for a longer duration are harmful to this crop. Sesame, being an important oil seed crop of the country, is grown in all the three growing season. Due to nutritional and medicinal values the crop is now gaining importance among the farmers, for which the demand of quality seed is increased. Quality seeds are considered as crucial and important input in crop production. Enhancement of crop yields to the extent of $20-25 \%$ has been reported (Singhal and Vari, 2002). Among various factors influencing quality seed production, the influence of growing season 
appears significant in expression of various morphological, physiological and biochemical traits which ultimately determines the productivity of crop and sowing quality of seed (Nema, 1989). Therefore selection of appropriate growing season is important while planning for seed production. The present study is undertaken to identify the most suitable growing season for planning quality seed production in sesame with five varieties/genotypes of sesame.

\section{Materials and Methods}

The experiment was conducted at the Central Research Station, Orissa University of Agriculture and Technology, Bhubaneswar, situated at $20015^{\prime} \mathrm{N}$ latitude and 850 52' longitudes. Five varieties or genotypes were used in this experiment i.e., Uma, Nirmala, Amrit, Cums 17, Prachi and the seed crops were grown during summer, 2015, kharif 2015 and rabi 2015-16 to study the seasonal influence on the expression of chemomorphic traits determining seed yield and yield attributes of five sesame genotypes. The meterological conditions were suitable for raising the seed crops of sesame and the climatic parameters, rainfall, maximum and minimum temperatures, relative humidity and bright sunshine hours were recorded during the period of investigation (2014-2016) at the meterological observatory, OUAT, Bhubaneswar.

The five varieties were grown in plot size of $4.5 \times 3$ sq. $m$ with spacing $30 \mathrm{~cm} \times 10 \mathrm{~cm}$. The experiment was laid in randomized block design with four replications. Appropriate seed production technology (Agrawal, 2003) was adopted to raise the seed crops. The desired preharvest observations viz. Days to appearance of flowering and 50\% flowering were recorded in the standing crops in whole plot basis. The pods of different treatments were harvested at harvestable maturity stage and seeds after threshing were sundried to about nine percent moisture level and stored in small clot bags under ambient condition.

\section{Results and Discussion}

The growing season is known to affect the expression of various plant growth parameters, seed yield attributes and seed quality parameters of crops. In the present investigation observations were recorded on various plant growth parameters namely days to initiation of flowering, days to completion of $50 \%$ flowering, days to initiation of capsules, plant height, and number of primary and secondary branches per plant in five different varieties/genotypes of sesame grown in three different seasons, the results of which are discussed below.

In the present study, days to initiation of flowering in five different varieties/genotypes of sesame was studied in three different growing seasons. Significant variations were observed among the sesame varieties/genotypes grown in all the three seasons. In summer season, the mean values ranged from 33.70 days (Prachi) to 36.00 days (CUMS 17) with an overall mean value of 34.86 days (Table-1). In kharif season the mean values ranged from 33.70 days (Prachi) to 36.33 days (Amrit) with an overall mean value of 35.13 days (Table-2). In rabi season the mean values ranged from 33.33 days (Prachi) to 36.33 days (CUMS 17) with an overall mean value of 34.93 days (Table-3). Analysis of mean values across the growing seasons indicated that the sesame variety Prachi was the earliest (33.57 days) and genotype CUMS 17 was the latest (35.88 days) to initiate flowering. The comparative study of the mean values of all the varieties/genotypes in three different seasons (Table-4) indicated that the earliest flowering occurs in summer season (34.86 days) while the latest flowering occurs in kharif season 
(35.33 days). The earliest flowering of the crop in summer could be due to accumulation of required growing degree days in a shorter period of time owing to increased temperature during the season. Seasonal variation in respect of flower initiation has been reported earlier (Kulkarni, 2012).

Like days to initiation of flowering, significant variations were also observed in respect of this character among the sesame varieties/genotypes grown in all the three seasons. In summer season the mean values of the varieties ranged from 40.70 days (Prachi) to 43.00 days (Amrit) with an overall mean value of 42.13 days (Table-1). In kharif season the mean values ranged from 40.70 days (Prachi) to 42.70 days (Amrit, Nirmala and CUMS 17) with an overall mean value of 40.20 days (Table-2). In rabi season the mean values of the varieties ranged from 40.33 days (Prachi) to 43.70 days (Uma) with an overall mean value of 40.06 days (Table-3). Across the growing season the sesame var. Prachi was found to be the earliest (40.57 days) and three varieties namely, Uma, Nirmala and CUMS 17 were the latest (42.57 days) to complete $50 \%$ flowering. The comparative study of the mean values of the sesame varieties in three different growing seasons (Table-4) indicated that the earliest flowering occurs in rabi season (42.06 days) while the latest flowering occurs in kharif season (42.20 days). The earlier ceasation of flowering in rabi could be prevalence of unfavourable weather conditions as compared to the other two seasons. Genetic diversity in respect of this trait has been reported in rapeseed (Jeena and Sheik, 2003).

Initiation of capsules is an important character of this crop. Significant variations among the sesame varieties/genotypes were observed only in two seasons except the summer season. In summer season the mean values in respect of this trait ranged from 49.00 days
(Prachi) to 50.70 days (Amrit, Nirmala and CUMS 17) with an overall mean value of 50.20 days (Table-1). In kharif season the mean values ranged from 49.70 days (Prachi) to 52.70 days (Amrit) with an overall mean value of 50.86 days (Table-2). In rabi season the mean values ranged from 49.00 days (Prachi) to 52.33 (Uma) with an overall mean value of 50.80 days (Table-3). Across the seasons, the sesame var. Prachi was the earliest (49.23 days) and Amrit was the latest (51.24 days) to inititate capsule formation. The comparative study of mean values of sesame varieties in different seasons indicated that the earliest initiation of capsules occurs in summer season (50.20 days) while latest capsule initiation occurs in kharif season (50.86 days). In the present study, similar trend was observed between the days to initiation of flowering and initiation of capsule. The sesame var. Prachi which was the earliest to flower also found to be the earliest to initiate capsule (Table-4). Similarly among the seasons the earliest flowering and capsule formation occurs in summer season which could be due to accumulation of required growing degree days in a shorter period of time owing to higher temperature prevalent during this season.

In the present investigation, significant variations among the sesame varieties/genotypes were observed in two seasons except the rabi season. In the summer season, the mean values ranged from 103.85 $\mathrm{cm}$ (Prachi) to $122.23 \mathrm{~cm}$ (Amrit) with an overall mean value of $117.72 \mathrm{~cm}$ (Table-1). In kharif season, the mean values ranged from $114.40 \mathrm{~cm}$ (Prachi) to $138.20 \mathrm{~cm}$ (Nirmala) with an overall mean value of $123.85 \mathrm{~cm}$ (Table-2). In rabi season, mean values ranged from $50.43 \mathrm{~cm}$ (Amrit) to $53.93 \mathrm{~cm}$ (Nirmala) with an overall mean value of $51.89 \mathrm{~cm}$. across the seasons the sesame var (Table-3). Prachi was the shortest $(89.91 \mathrm{~cm})$ and the Nirmala was the longest $(104.75 \mathrm{~cm})$ in plant 
height. The sesame var. Prachi was found to have the shortest height in all the three seasons while var. Nirmala was found to possess the highest plant height in kharif and summer seasons (Table-4). The comparative studies of mean value of sesame varieties in different seasons indicated that the shortest height of plants occurs in rabi season (51.89 $\mathrm{cm})$ while the tallest plant occurs in kharif season $(123.85 \mathrm{~cm})$. Since the length of vegetative phase is closely related to daily average temperature during crop growth, in the winter season as the minimum temperature was low that restricted vegetative growth resulting in development of shorter plants (Bhaumik et al., 2007). Several workers (Lewis and Woods, 2002; Zulfiqor and Asim, 2002; Jeen and Sheik, 2003) have reported presence of genotypic diversity and seasonal influence in respect of plant height in different crops.

Numbers of primary and secondary branches per plant are also other morphological characters determining yielding ability of the crop through development of photosynthetic area and reproductive growth of plant. The branching behaviour of number of primary branches plants is known to be greatly influenced by the environmental conditions prevalent during crop growth. In the present study, the branching behaviour of five sesame varieties/genotypes were studied in terms of number of primary and secondary branches per plant.

The results indicated absence of significant variations among the sesame varieties/genotypes grown in all the three seasons. In summer season, mean values in respect of this trait among the varieties/ genotypes ranged from 10.00 (Uma) to 11.33 (Prachi) with an overall mean value of 10.60 (Table-1). In kharif season, all the sesame varieties/genotypes exhibited same number of primary branches (Table-2). In rabi season, the mean values of the varieties ranged from 10.00 (Amrit, Nirmala and Prachi) to 11.00 (CUMS 17) with an overall mean value of 10.26 (Table-3).

Across the seasons, the sesame varieties Amrit and Uma possessed the least (10.11) and CUMS 17, the highest (10.55) number of primary branches. However, comparative study of mean values of the genotypes in three different seasons indicated that the least number (10.00) of primary branches occurs in kharif season while the highest number (10.60) occurs in the summer season (Table4). The presence of non-significant differences between the mean value of three seasons revealed that this character is not much influenced by growing seasons.

On the other hand significant differences among the sesame varieties/genotypes were observed in respect of number of secondary branches per plant in three seasons. In summer season, the mean values of varieties ranged from 25.00 (CUMS 17) to 43.00 (Amrit) with an overall mean value of 35.00 . In kharif season, the values ranged from 7.00 (Uma) to 12.67 (CUMS 17 and Prachi) with an overall mean value of 11.00. In rabi season, mean values ranged from 0.00 (Uma) to 10.70 (CUMS 17) with an overall mean value of 6.60 .

Across the seasons, the sesame cv. Uma possessed the least (14.66) and Amrit, the highest (20.66) number of secondary branches per plant. The comparative study of the mean values in three different seasons indicated that the least number (6.60) of secondary branches occurs in summer season. Unlike primary branches this character is greatly influenced by the growing season.

Since the length of vegetative phase is closely related to daily average temperature during crop growth, minimum number of branches 
developed in the plants in winter season due to restricted vegetative growth, significant variation in the branching behaviour has been reported (Lewis and Woods, 2002; Jeena and Sheik, 2003) in long podded rapeseed lines.

Number of fruits or capsules per plant is an important contributor of yield. In the present study significant variations among the sesame varieties/genotypes were present in two seasons except rabi season. In summer season, the mean values of different varieties ranged from 50.60 (Uma) to 75.50 (Nirmala) with an overall mean value of 60.52 (Table1). In kharif season, mean values ranged from 66.27 (Nirmala) to 77.50 (Prachi) with an overall mean value of 70.20 (Table-2). In rabi season, mean values ranged from 40.67 (Uma) to 42.60 (Amrit) with an overall mean value of 41.81 (Table-3).

Across the seasons the sesame var. Uma possessed the least (53.12) and Nirmala, the highest (61.01) number of capsules per plant. The comparative study of mean values of sesame varieties/genotypes in three different seasons indicated that the least number (41.81) of capsules per plant occurs in rabi season while the highest number (70.20) of capsules per plant occurs in kharif season (Table-4). The restricted vegetative growth of the plants in rabi season might be the reason for development of reduced number of capsules per plant. Genetic diversity in respect of this character has been reported in rapeseed (Jeena and Sheik, 2003), and Sesamum mulayanum (Valamathi et al., 2003).

Number of seeds per capsule is another important yield attribute of crop plants. Better growing conditions of the seed crop particularly at reproductive phase results in higher seed set their by increase in number of seeds per fruit. Any factor which affects pollen viability and pollination has adverse effect on this trait.
In the present investigation, significant variations were observed among sesame varieties/genotypes in respect of this trait grown in all the three seasons. In summer season, the mean values of different varieties ranged from 46.20 (CUMS 17) to 52.58 (Nirmala) with an overall mean value of 48.92 (Table-1). In kharif season mean values ranged from 49.03 (CUMS 17) to 56.78 (Prachi) with an overall mean value of 52.35 (Table-2), in rabi season, mean values ranged from 38.37 (Prachi) to 45.75 (Amrit) with an overall mean value of 41.33 (Table-3). Across the seasons, the sesame genotype CUMS 17 possessed the least (45.20) and Nirmala, the highest (48.69) number of seeds per capsule. Comparative study of mean values of sesame varieties/genotypes in three different seasons indicated that the least number (41.33) occurs in rabi season while the highest (52.35) number of seeds per capsule occurs in kharif season (Table-4). The unfavorable climatic conditions particularly low temperature prevalent during rabi season might have restricted the fertilization process which resulted in formation of less number of seeds in the capsules.

The weight of capsule is an indicator of number of seeds per capsule higher fruit weight is often related to higher seed yield. In the present study, significant variations were observed among the sesame varieties/genotypes in all the three seasons in respect of this trait.

In summer season, the mean values of different varieties ranged from $0.33 \mathrm{~g}$ (Prachi) to $0.46 \mathrm{~g}$ (Uma) with an overall mean value of 0.41g (Table-1). In kharif season, mean values ranged from $0.46 \mathrm{~g}$ (CUMS 17) to $0.63 \mathrm{~g}$ (Nirmala) with an overall mean value of $0.55 \mathrm{~g}$ (Table-2). In rabi season, mean values ranged from 0.41g (Amrit and CUMS 17) to $0.46 \mathrm{~g}$ (Prachi) with an overall mean value of $0.43 \mathrm{~g}$ (Table- 3 ). 
Table.1 Effect of summer season on Cheo-Morphic and seed yield characteristics of sesame varieties

\begin{tabular}{|c|c|c|c|c|c|c|c|c|c|c|c|c|c|c|}
\hline Varieties & $\begin{array}{c}\text { Days to } \\
\text { initiation of } \\
\text { flowering }\end{array}$ & $\begin{array}{l}\text { Days to } 50 \% \\
\text { of flowering }\end{array}$ & $\begin{array}{c}\text { Initiation } \\
\text { of } \\
\text { capsule }\end{array}$ & $\begin{array}{c}\text { Plant } \\
\text { height } \\
(\mathrm{cm})\end{array}$ & $\begin{array}{c}\text { Primary } \\
\text { branch }\end{array}$ & $\begin{array}{c}\text { Secondary } \\
\text { branch }\end{array}$ & $\begin{array}{c}\text { No. of } \\
\text { capsule/ } \\
\text { Plant }\end{array}$ & $\begin{array}{c}\text { Fresh } \\
\text { capsule } \\
\text { Weight }(\mathrm{g})\end{array}$ & $\begin{array}{l}\text { Capsule } \\
\text { length } \\
(\mathrm{cm})\end{array}$ & $\begin{array}{c}\text { Capsul } \\
\text { e width } \\
(\mathrm{cm})\end{array}$ & $\begin{array}{c}\text { Capsule } \\
\text { thickness } \\
(\mathrm{cm})\end{array}$ & $\begin{array}{c}\text { No. Of } \\
\text { seeds/ } \\
\text { Capsule }\end{array}$ & $\begin{array}{c}1000 \\
\text { Seed } \\
\text { weight }(g)\end{array}$ & $\begin{array}{c}\text { Seed } \\
\text { yield } \\
/ \text { plant }(\mathrm{g})\end{array}$ \\
\hline UMA & 34.33 & 41.70 & 50.00 & 120.32 & 10.00 & 37.00 & 50.60 & 0.46 & 1.94 & 0.63 & 0.77 & 47.58 & 2.87 & 7.532 \\
\hline AMRIT & 35.00 & 43.00 & 50.70 & 122.23 & 10.33 & 43.00 & 67.50 & 0.40 & 1.75 & 0.65 & 0.77 & 48.43 & 2.84 & 8.275 \\
\hline NIRMALA & 35.33 & 42.70 & 50.70 & 122.13 & 10.70 & 35.00 & 75.50 & 0.43 & 1.74 & 0.62 & 0.78 & 52.58 & 2.96 & 8.045 \\
\hline PRACHI & 33.70 & 40.70 & 49.00 & 103.85 & 11.33 & 35.00 & 54.10 & 0.33 & 1.76 & 0.63 & 0.77 & 49.83 & 3.41 & 9.146 \\
\hline CUMS 17 & 36.00 & 42.70 & 50.70 & 120.10 & 10.70 & 25.00 & 54.90 & 0.43 & 1.76 & 0.62 & 0.78 & 46.20 & 2.45 & 8.327 \\
\hline $\begin{array}{l}\text { GRAND } \\
\text { MEAN }\end{array}$ & 34.86 & 42.13 & 50.20 & 117.72 & 10.60 & 35.00 & 60.52 & 0.41 & 1.78 & 0.62 & 0.77 & 48.92 & 2.906 & 8.265 \\
\hline $\mathrm{CD}(0.05)$ & 0.773 & 1.635 & NS & 5.26 & NS & 6.02 & 0.911 & 0.01 & NS & NS & NS & 1.418 & 0.194 & 0.896 \\
\hline $\mathrm{CV}(\%)$ & 1.247 & 2.181 & 2.673 & 13.33 & 6.59 & 9.67 & 0.846 & 2.25 & 4.54 & 2.64 & NS & 1.629 & 3.757 & 10.894 \\
\hline
\end{tabular}

Table.2 Effect of Kharif season on Cheo-Morphic and seed yield characteristics of sesame varieties

\begin{tabular}{|c|c|c|c|c|c|c|c|c|c|c|c|c|c|c|}
\hline Varieties & $\begin{array}{c}\text { Days to } \\
\text { initiation of } \\
\text { flowering }\end{array}$ & $\begin{array}{c}\text { Days to } \\
50 \% \text { of } \\
\text { flowering }\end{array}$ & $\begin{array}{c}\text { Initiation } \\
\text { of } \\
\text { capsule }\end{array}$ & $\begin{array}{c}\text { Plant } \\
\text { height } \\
(\mathrm{cm})\end{array}$ & $\begin{array}{c}\text { Primary } \\
\text { branch }\end{array}$ & $\begin{array}{c}\text { Secondary } \\
\text { branch }\end{array}$ & $\begin{array}{c}\text { No. of } \\
\text { capsule/ } \\
\text { Plant }\end{array}$ & $\begin{array}{c}\text { Fresh } \\
\text { capsule } \\
\text { Weight }(\mathrm{g})\end{array}$ & $\begin{array}{l}\text { Capsule } \\
\text { length } \\
(\mathrm{cm})\end{array}$ & $\begin{array}{c}\text { Capsul } \\
\text { e width } \\
(\mathrm{cm})\end{array}$ & $\begin{array}{c}\text { Capsule } \\
\text { thickness } \\
(\mathrm{cm})\end{array}$ & $\begin{array}{c}\text { No. Of } \\
\text { seeds/ } \\
\text { Capsule }\end{array}$ & $\begin{array}{c}1000 \\
\text { Seed } \\
\text { weight }(\mathrm{g})\end{array}$ & $\begin{array}{c}\text { Seed } \\
\text { yield } \\
\text { /plant }(\mathrm{g})\end{array}$ \\
\hline UMA & 35.33 & 42.33 & 50.33 & 121.50 & 10.00 & 7.00 & 68.10 & 0.54 & 2.21 & 0.62 & 0.78 & 49.99 & 2.75 & 8.875 \\
\hline AMRIT & 36.33 & 42.70 & 52.70 & 117.05 & 10.00 & 11.00 & 66.83 & 0.52 & 2.27 & 0.62 & 0.76 & 51.40 & 2.68 & 9.727 \\
\hline NIRMALA & 35.00 & 42.70 & 51.00 & 138.20 & 10.00 & 11.67 & 66.27 & 0.63 & 2.38 & 0.64 & 0.76 & 54.55 & 3.02 & 9.623 \\
\hline PRACHI & 33.70 & 40.70 & 49.70 & 114.90 & 10.00 & 10.70 & 77.50 & 0.46 & 2.11 & 0.63 & 0.75 & 56.78 & 3.52 & 9.862 \\
\hline CUMS 17 & 35.33 & 42.70 & 50.70 & 127.60 & 10.00 & 17.70 & 72.30 & 0.62 & 2.21 & 0.63 & 0.75 & 49.03 & 2.23 & 9.883 \\
\hline $\begin{array}{l}\text { GRAND } \\
\text { MEAN }\end{array}$ & 35.13 & 42.13 & 50.86 & 123.85 & 10.00 & 11.00 & 70.20 & 0.55 & 2.23 & 0.62 & 0.76 & 52.35 & 2.840 & 9.594 \\
\hline $\mathrm{CD}(0.05)$ & 0.817 & 1.635 & 1.535 & 6.57 & NS & 2.002 & 1.395 & 0.02 & 0.08 & NS & NS & 0.545 & 0.181 & 0.216 \\
\hline $\mathrm{CV}(\%)$ & 1.308 & 2.181 & 1.696 & 2.98 & 0.00 & 10.23 & 1.117 & 2.81 & 2.05 & 1.74 & NS & 0.585 & 3.587 & 9.010 \\
\hline
\end{tabular}


Table.3 Effect of Rabi season on Cheo-Morphic and seed yield characteristics of sesame varieties

\begin{tabular}{|c|c|c|c|c|c|c|c|c|c|c|c|c|c|c|}
\hline Varieties & $\begin{array}{l}\text { Days to } \\
\text { initiation of } \\
\text { flowering }\end{array}$ & $\begin{array}{l}\text { Days to } \\
50 \% \text { of } \\
\text { flowering }\end{array}$ & $\begin{array}{c}\text { Initiatio } \\
\mathrm{n} \text { of } \\
\text { capsule }\end{array}$ & $\begin{array}{l}\text { Plant } \\
\text { height } \\
(\mathrm{cm})\end{array}$ & $\begin{array}{l}\text { Primary } \\
\text { branch }\end{array}$ & $\begin{array}{l}\text { Secondar } \\
\text { y branch }\end{array}$ & $\begin{array}{c}\text { No. of } \\
\text { capsule/ } \\
\text { Plant }\end{array}$ & $\begin{array}{c}\text { Fresh } \\
\text { capsule } \\
\text { Weight } \\
\text { (g) }\end{array}$ & $\begin{array}{c}\text { Capsule } \\
\text { length } \\
(\mathrm{cm})\end{array}$ & $\begin{array}{c}\text { Capsul } \\
\text { e } \\
\text { width } \\
(\mathrm{cm})\end{array}$ & $\begin{array}{c}\text { Capsule } \\
\text { thicknes } \\
\mathrm{s}(\mathrm{cm})\end{array}$ & $\begin{array}{c}\text { No. Of } \\
\text { seeds/ } \\
\text { Capsule }\end{array}$ & $\begin{array}{c}1000 \\
\text { Seed } \\
\text { weight }(\mathrm{g})\end{array}$ & $\begin{array}{c}\text { Seed } \\
\text { yield } \\
\text { /plant } \\
\text { (g) }\end{array}$ \\
\hline UMA & 34.70 & 43.70 & 52.33 & 51.13 & 10.33 & 0.00 & 40.67 & 0.42 & 1.92 & 0.68 & 0.81 & 43.23 & 2.06 & 4.872 \\
\hline AMRIT & 35.33 & 41.70 & 50.33 & 50.43 & 10.00 & 8.00 & 42.60 & 0.41 & 2.07 & 0.68 & 0.82 & 45.75 & 2.08 & 5.143 \\
\hline NIRMALA & 35.00 & 42.33 & 51.70 & 53.93 & 10.00 & 5.00 & 41.70 & 0.44 & 2.05 & 0.70 & 0.84 & 38.95 & 2.32 & 4.879 \\
\hline PRACHI & 33.33 & 40.33 & 49.00 & 51.00 & 10.00 & 9.33 & 42.00 & 0.46 & 1.91 & 0.67 & 0.85 & 38.37 & 2.43 & 5.615 \\
\hline CUMS 17 & 36.33 & 42.33 & 50.70 & 52.97 & 11.00 & 10.70 & 42.10 & 0.41 & 2.19 & 0.68 & 0.89 & 40.37 & 1.86 & 4.725 \\
\hline $\begin{array}{l}\text { GRAND } \\
\text { MEAN }\end{array}$ & 34.93 & 42.06 & 50.80 & 51.89 & 10.26 & 6.60 & 41.81 & 0.43 & 2.02 & 0.67 & 0.84 & 41.33 & 2.150 & 5.047 \\
\hline $\mathrm{CD}(0.05)$ & 0.992 & 1.171 & 1.912 & NS & NS & 6.30 & NS & 0.03 & 0.16 & NS & 0.02 & 0.577 & 0.166 & 0.172 \\
\hline $\mathrm{CV}(\%)$ & 1.597 & 1.565 & 2.116 & 9.850 & 6.730 & 53.73 & 2.004 & 4.56 & 4.44 & 3.03 & 1.845 & 0.784 & 4.347 & 9.010 \\
\hline
\end{tabular}

Table.4 Chemo-Morphic and seed yield characteristics of sesame varieties (pooled over seasons)

\begin{tabular}{|c|c|c|c|c|c|c|c|c|c|c|c|c|c|c|}
\hline Varieties & $\begin{array}{c}\text { Days to } \\
\text { initiation } \\
\text { of } \\
\text { flowering }\end{array}$ & $\begin{array}{c}\text { Days to } \\
50 \% \text { of } \\
\text { flowering }\end{array}$ & $\begin{array}{c}\text { Initiatio } \\
\mathrm{n} \text { of } \\
\text { capsule }\end{array}$ & $\begin{array}{l}\text { Plant height } \\
(\mathrm{cm})\end{array}$ & $\begin{array}{l}\text { Primary } \\
\text { branch }\end{array}$ & $\begin{array}{l}\text { Secondar } \\
\text { y branch }\end{array}$ & $\begin{array}{c}\text { No. of } \\
\text { capsule } \\
\text { / } \\
\text { Plant } \\
\end{array}$ & $\begin{array}{c}\text { Fresh } \\
\text { capsule } \\
\text { Weight } \\
(\mathrm{g})\end{array}$ & $\begin{array}{c}\text { Capsule } \\
\text { length } \\
(\mathrm{cm})\end{array}$ & $\begin{array}{l}\text { Capsu } \\
\text { le } \\
\text { width } \\
(\mathrm{cm})\end{array}$ & $\begin{array}{l}\text { Capsule } \\
\text { thickne } \\
\mathrm{ss}(\mathrm{cm})\end{array}$ & $\begin{array}{c}\text { No. Of } \\
\text { seeds/ } \\
\text { Capsule }\end{array}$ & $\begin{array}{c}1000 \\
\text { Seed } \\
\text { weight( } \\
\text { g) }\end{array}$ & $\begin{array}{c}\text { Seed } \\
\text { yield } \\
\text { /plant } \\
(\mathrm{g})\end{array}$ \\
\hline UMA & 34.78 & 42.57 & 50.88 & 97.65 & 10.11 & 14.66 & 53.12 & 0.47 & 2.02 & 0.64 & 0.78 & 46.93 & 2.56 & 7.093 \\
\hline AMRIT & 35.55 & 42.46 & 51.24 & 96.57 & 10.11 & 20.66 & 58.97 & 0.44 & 2.03 & 0.65 & 0.78 & 48.69 & 2.53 & 7.715 \\
\hline NIRMALA & 35.11 & 42.57 & 51.13 & 104.75 & 10.22 & 17.22 & 61.01 & 0.50 & 2.05 & 0.65 & 0.79 & 48.69 & 2.76 & 8.045 \\
\hline PRACHI & 33.57 & 40.57 & 49.23 & 89.91 & 10.44 & 19.00 & 57.86 & 0.41 & 1.92 & 0.64 & 0.79 & 47.99 & 3.12 & 8.207 \\
\hline CUMS 17 & 35.88 & 42.57 & 50.70 & 100.22 & 10.55 & 16.12 & 56.43 & 0.48 & 2.05 & 0.64 & 0.80 & 45.20 & 2.18 & 7.645 \\
\hline GRAND MEAN & 34.97 & 42.13 & 50.62 & 97.82 & 10.28 & 17.53 & 57.51 & 0.46 & 2.01 & 0.63 & 0.79 & 47.53 & 2.632 & 7.635 \\
\hline
\end{tabular}


Across the seasons the sesame var. Prachi possessed the lowest $(0.41 \mathrm{~g})$ and Nirmala, the highest $(0.50 \mathrm{~g})$ fresh capsule weight. The comparative study of the sesame varieties/genotypes in three different seasons indicated that the lowest capsule weight $(0.41 \mathrm{~g})$ occurs in summer season while the highest $(0.44 \mathrm{~g})$ capsule weight occurs in kharif season (Table-4). Favorable environmental condition prevalent during kharif season might have favoured fruit and seed development resulting in formation of heavier fruits/capsules.

The size of capsules at the maturity stage of the crop is also an indicator of number of seeds present in the fruit/capsule which ultimately determines the yield potential of crop. In the present study, the size of freshly harvested capsules was measured in terms of length, width and thickness. In the present study, significant variations were observed among the sesame varieties/genotypes only in respect of fresh capsule length grown in kharif and rabi seasons and fresh capsule thickness grown in rabi season. In summer season, the mean values of different varieties/genotypes in respect of capsule length ranged from $1.74 \mathrm{~cm}$ (Nirmala) to 1.94 cm (Uma) with an overall mean value of 1.78 cm (Table-1). In kharif season, mean values ranged from $2.11 \mathrm{~cm}$ (Prachi) to $2.38 \mathrm{~cm}$ (Nirmala) with an overall mean value of 2.23 cm (Table-2). In rabi season, mean values ranged fom $1.91 \mathrm{~cm}$ (Prachi) to $2.19 \mathrm{~cm}$ (CUMS 17) with an overall mean value of $2.02 \mathrm{~cm}$ (Table-3). Across the seasons, the sesame var. Prachi possessed the smallest $(1.92 \mathrm{~cm})$ and Nirmala and CUMS 17, possessed the longest $(2.05 \mathrm{~cm})$ fresh capsule length. The comparative study of mean values of sesame varieties/genotypes in three different seasons indicated that the smallest capsule $(1.78 \mathrm{~cm})$ were produced in summer season while the longest capsule $(2.23 \mathrm{~cm})$ occurs in kharif season (Table-4).
On the other hand, a significant variation among the varieties in respect of fresh capsule thickness was only observed in rabi season and not in other two seasons. In this case the mean values of varieties in summer season ranged from $0.77 \mathrm{~cm}$ (Uma, Amrit and Prachi) to $0.78 \mathrm{~cm}$ (Nirmala and CUMS 17) with an overall mean value of $0.77 \mathrm{~cm}$ (Table1). In kharif season, the mean values ranged from $0.75 \mathrm{~cm}$ (CUMS 17 and Prachi) to 0.78 $\mathrm{cm}$ (Uma) with an overall mean value of 0.76 cm (Table-2). In rabi season mean values ranged from $0.81 \mathrm{~cm}$ (Uma) to $0.89 \mathrm{~cm}$ (CUMS 17) with an overall mean value of $0.87 \mathrm{~cm}$ (Table-3).

Across the seasons, the sesame varieties Uma and Amrit possessed the thinnest $(0.78 \mathrm{~cm})$ and CUMS 17, the thickest $(0.80 \mathrm{~cm})$ capsule. The comparative study of the mean values of different genotypes in three different seasons indicated that the thinnest $(0.76 \mathrm{~cm})$ capsules were observed in kharif season while the thickest capsule $(0.84 \mathrm{~cm})$ occurs in rabi season (Table-4).

Among various factors responsible for quality seed production, seed size has significant influence on both seed yield and quality. In the present study, significant variations were observed in respect of this trait among the sesame varieties/genotypes grown in all the three seasons. In summer season, the mean values of different varieties/genotypes ranged from 2.45g (CUMS 17) to 3.41g (Prachi) with an overall mean value of $2.90 \mathrm{~g}$ (Table-1). In kharif season, the mean values ranged from 2.23g (CUMS 17) to 3.52g (Prachi) with an overall mean value of $2.84 \mathrm{~g}$ (Table-2). In rabi season, the mean values ranged from $1.86 \mathrm{~g}$ (CUMS 17) to $2.43 \mathrm{~g}$ (Prachi) with an overall mean value of $2.15 \mathrm{~g}$ (Table-3). Across the seasons, the sesame genotype CUMS 17 possessed the lowest $(2.18 \mathrm{~g})$ and Prachi, the highest $(3.12 \mathrm{~g})$ weight per 1000 seeds. The comparative study of the mean value of 
sesame varieties/genotypes in three different seasons indicated that the lowest $(2.15 \mathrm{~g})$ weight of 1000 seeds occur in rabi season while it was highest $(2.90 \mathrm{~g})$ in summer season (Table-4). The favourable environmental conditions prevalent during summer and kharif season might have favoured greater translocation of photosynthates to the developing seeds resulting in formation of bold seeds. On the other hand the unfavourable environmental conditions of rabi season didn't favoured crop growth which was reflected in the formation of smaller seeds. Seasonal variation in respect of this character has been reported earlier in sorghum hybrid CSH-5 (Narasimhamurthy, 1982), in paddy cv. Pusa Basmati-1 (Singh et al., 2002). Seed yield is an important consideration in any study relating into commercial cultivation as well as seed production of a crop. The yield potential of sesame varieties/genotypes in the present investigation was assessed only on per plant basis. The seed yield per plant depends upon number of mature capsules per plant, seeds per capsule and average seed weight which are considered being the important components of yield. The effect of any factor on yield components are integrated and expressed in the seed yield. In the present investigation significant variations were present among the sesame varieties/genotypes grown in all the three seasons in respect of this yield parameter. In the summer season the mean values of different varieties ranged from 4.53g (Uma) to $9.14 \mathrm{~g}$ (Prachi) with an overall mean value of $8.26 \mathrm{~g}$ (Table-1). In kharif season, the mean values ranged from $8.87 \mathrm{~g}$ (Uma) to $9.88 \mathrm{~g}$ (CUMS 17) with an overall mean value of $9.59 \mathrm{~g}$ (Table-2). In rabi season the mean values ranged from $4.72 \mathrm{~g}$ (CUMS 17) to 5.61g (Prachi) with an overall mean value of $5.04 \mathrm{~g}$ (Table-3). Across the seasons the sesame var. Uma produced the lowest (7.093g) and Prachi, the highest $(8.207 \mathrm{~g})$ per plant seed yield. The comparative study of the mean values of sesame varieties/genotypes in three different seasons indicated that the lowest $(5.047 \mathrm{~g})$ and the highest $(9.594 \mathrm{~g})$ per plant seed yield were obtained in rabi and kharif season, respectively (Table-4). The higher seed yield observed in kharif and summer seasons in comparison to rabi season might be due to the influence of growing conditions for better expression of yield attributing traits viz., number of mature capsules per plant, seeds per capsule and seed weight. Seasonal variation in respect of this character has been reported earlier in bajra hybrid BJ104 (Raja Rao, 1981), broad bean (Tomar et al., 2002), gaillardia (Hugar et al., 1998), green gram (Barua and Barua, 2000), Sunflower (Vyakarnhal et al., 2002, Pathak, 1975; Shabana, 1975 and Kathiresan and Ramaswamy, 1978).

In conclusion the pooled values of different traits over 3 growing seasons indicated that Prachi was the earliest to initiate flowering (33.57 days) and complete 50\% flowering (40.57 days), 1000 seed weight(3.12g) and per plant seed yield $(8.207 \mathrm{~g})$. However, the higher seed yield $(8.045 \mathrm{~g})$ in Nirmala was due to increased number of capsules per plant (61.01) and number of seeds per capsule (48.69).

\section{References}

Agrawal, R.L. 2003. Seed Technology. Edn. II, Oxford and IBH Pub. Pp. 829.

Barua, M. and Barua, P.K. 2000. Seasonal effect on seed yield and quality in green gram. Seed Res., 28(2): 153-157

Bhaumik, S.B., Sharma, S.P. and Dadlani, M 2007. Effect of season on crop growth, flowering, synchronization pattern and seed yield in the parental lines of maize hybrids. Seed Res., 35(2): 139- 147

Hugar, A.N., Nalwadi, U.G., Ravi Kumar, G.H., Basave Gouda and Patil, M.G. 1998. Intluence of nitrogen on seed yield and 
quality parameters in gaillardia (Gaillardia pulchella). Seed Tech. News, 28(4): 83.

Jeena, A.S. and Sheik, F.A. 2003. Genetic divergence analysis in gobhi sarson, Brassica napus L. J. Oilseeds Res., 20(2): 210-212.

Kathiresan, M. and Ramaswamy, K.R. 1978. Effect of time of sowing on seed yield and seed quality in sunflower (Helianthus annus). Seed Res., 6(2): 118- 124.

Kulkarrni, G.N. 2012. Recent Advances in Seed Quality, Kalyani Publishers Ludhiana pp286-2955.

Lewis, L.J. and Woods, D.L. 2002. Germplasm release of long podded summer turnip rape (Brassica rapa L.). Cruciferae Newsl., (24): 63.

Nagarjan, S., Sinha, J.P. and Pandita, V.K. 2004. Effect of sowing dates, spacing and nitrogen levels on seed yield and quality in okra. Seed Res., 32(2): 128-121

Nanda, J.S. and Agrawal, P.K. 2009. Botany of Field Crops, vol.1, Kalyani Publishers., Ludhiana. pp: 287-292

Noorka, I.R., S.I. Hafiz and M.A.S. ElBramawy. 2011. Response of sesame to population densities and nitrogen fertilization on newly reclaimed sandy soils. Pak. J. Bot., 43: 1953-1958.

Pathak, R.S. 1975. Yield components in sunflower. Proceedings VI, International sunflower conference July 22-24, 1974, Buchrast, Romania, Genetics, Edited by Vranceanu, A.V, 271-282.
Raja rao, M.K. 1981. Evaluation of Planting Ratios of Parental Lines for BJ-104 Hybrid Pearl Millet Production. Seed Res., 14(2): 241-243.

Shabana, R. 1975. Genetic variability of sunflower varieties and inbred lines. In proceedings of 6 th International Sunflower Conference, Bucharest Romania, 263-269.

Shinde, P.Y., Patil, R. and Puskor, M. 1998. comprehensive studies on the influence of sowing season on groundnut seed quality. Seed Tech News, 28(4): 74

Tomar, B.S., Negi, H.C.S. and Singh, N.K. 2002. Influence of sowing time on seed And quality traits in broad bean (Vicia faba L) cv Pusa summet. Seed Tech News, 32(1): 75-76.

Valarmathi, G., Surendran, C., Vanniarajan, C., Kumar, M. and Saravanan, N.A. 2003. Morphological and biochemical characterization of sesame (Sesamum indicum L. and S. mulayanum L.). Sesame and Safflower Newslett., 18: 4246.

Vyakaranahal, B.S., Shekhargouda, M., Patil, S.A. and Prabhakar, A.S. 2002. Effect of Nipping of Side Branches in RHA-857 Restorer Line of DSH-1 Sunflower Hybrid. Seed Tech. News, 32(1): 53.

Zulfiqar, A.M. and Asim, M. 2002. Fodder Yield and Quality Evaluation of the Sorghum Varieties. J. Agron., 1: 60-63.

\section{How to cite this article:}

Monalisa S.P. and Swain S.K. 2017. Chemo-Morphic Traits Determining Seed Yield in Sesame As Influenced By Growing Seasons. Int.J.Curr.Microbiol.App.Sci. 6(5): 2561-2570. doi: https://doi.org/10.20546/ijcmas.2017.605.288 